\title{
EFEKTIVITAS PELAKSANAAN SUPERVISI AKADEMIK KEPALA SEKOLAH DALAM MENINGKATKAN KINERJA GURU DI SMK NEGERI 4 BANDAR LAMPUNG
}

\author{
Ela Krisdiana ${ }^{1}$, Sudirman Aminin ${ }^{2 *}$ Riyanto $^{3 *}$ \\ ${ }_{1,2,3}$ Universitas Muhammadiyah Metro \\ Email: krisdianaella4@gmail.com \\ sudirman.am57@gmail.com \\ riyantoto56@gmail.com
}

\begin{abstract}
Abstrak
Supervisi akademik yang diterapkan kepala sekolah tentunya sangat efektif, karena dapat memberikan bantuan, bimbingan dan pembinaan kepada kinerja guru agar mereka mampu bekerja lebih baik dalam membimbing peserta didik serta dapat memperbaiki kinerjanya dalam meningkatkan pembelajaran di sekolah. Fokus penelitian dalam penelitian tesis ini adalah: (1) Bagaimana pelaksanaan supervisi akademik kepala sekolah, (2) Bagaiman cara meningkatkan kinerja guru (3) Bagaimana efektivitas supervisi akademik Kepala Sekolah dalam meningkatkan kinerja guru. Tujuan penelitian adalah Untuk mendeskripsikan pelaksanaan supervisi akademik, cara meningkatkan kinerja guru, efektivitas Supervisi akademik Kepala Sekolah dalam meningkatkan kinerja guru di SMK Negeri 4 Bandar Lampung. Penelitian ini menggunakan pendekatan kualitatif dengan metode deskriptif. Teknik pengumpulan data dilakukan melalui wawancara, observasi, dan dokumentasi. Teknik analisis data yang digunakan yaitu analisis data tunggal. Dari hasil penelitian ini, peneliti menyimpulkan bahwa: (1) Pelaksanaan supervisi akademik kepala sekolah meliputi penyusunan Program kerja terdiri dari program tahunan dan program semester, kepala sekolah melakukan supervisi terhadap guru di mulai dari metode pengajaran sampai dengan aktifitas guru. (2) Meningkatkan kinerja guru meliputi: Program pelatihan didalam sekolah seperti bedah kurikulum, penyusunan perangkat, program pelatihan diluar sekolah seperti workshop, peningkatan kompetensi penulisan karya ilmiah, peningkatan kompetensi guru mata pelajaran, pelatihan penyusunan naskah soal ujian sekolah berstandar nasional. (3) Evektifitas supervisi akademik kepala sekolah dalam meningkatkan kinerja guru meliputi: Melakukan evaluasi seperti penilaian, pembinaan, pemantauan, dan analisis hasil pengawasan dalam satu semester. pelaksanaan tindak lanjut supervisi, bentuk tindak lanjut supervisi akademik dapat dilakukan melalui kegiatan pembinaan langsung dan tidak langsung.
\end{abstract}

Kata kunci: Supervisi Akademik, Kepala sekolah, kinerja guru

\begin{abstract}
Academic supervision applied by the principal is certainly very effective, because it can provide assistance, guidance and coaching to the performance of teachers so that they are able to work better in guiding students and can improve their performance in improving learning in schools. The focus of the research in this thesis research are: (1) How is the implementation of the principal's academic supervision, (2) How to improve teacher performance, (3) How is the effectiveness of the principal's academic supervision in improving teacher performance. The purpose of the study was to describe the implementation of academic supervision, how to improve teacher performance, the effectiveness of the principal's academic supervision in improving teacher performance at SMK Negeri 4 Bandar Lampung. This study uses a qualitative approach with a descriptive method. Data collection techniques were carried out through interviews, observation, and documentation. The data analysis technique used is single data analysis. From the results of this study, the researchers concluded that: (1) The implementation of the principal's academic supervision includes the preparation of a work program consisting of annual programs and semester programs, the principal supervises teachers starting from teaching methods to teacher activities. (2) Improving teacher performance includes: In-school training programs such as curriculum review, preparation of tools, training programs outside of schools such as workshops, improvement of scientific writing competence, improvement of subject teachers' competence, training in drafting national standard school exam questions. (3) The effectiveness of the principal's academic supervision in improving teacher performance includes: Conducting evaluations such as assessment, coaching, monitoring, and analysis of the results of supervision in one semester. implementation of follow-up supervision, follow-up forms of academic supervision can be carried out through direct and indirect coaching activities.
\end{abstract} Keywords: Academic Supervision, Principal, Teacher performance 


\section{PENDAHULUAN}

Efektivitas sebuah sekolah yang berkualitas sangat ditentukan oleh kinerja dari semua unsur yang terlibat dalam proses pelaksanaan kegiatan sekolah. Salah satu unsur yang dalam menentukan keberhasilan kegiatan belajar mengajar adalah guru. Seorang guru harus mempunyai kinerja yang baik guna meningkatkan kualitas pendidikan. Keberhasilan ataupun kegagalan sebuah proses pendidikan sangat ditentukan oleh kemampuan dan kinerja guru itu sendiri. Guru yang mempunyai kemampuan kerja yang tinggi dapat mengelola proses pembelajaran secara optimal sehingga dapat mencapai hasil yang maksimal. Kinerja guru mempunyai spesifikasi tertentu. Kinerja guru dapat dilihat dan diukur berdasarkan spesifikasi atau kriteria kompetensi yang harus dimiliki oleh setiap guru. Kinerja guru dapat dilihat saat dia melaksanakan interaksi belajar mengajar di kelas termasuk persiapannya baik dalam bentuk program semester maupun persiapan mengajar. Pembinaan terhadap guru baik melalui workshop, penilaian kinerja guru, diskusi dan supervisi harus terus menerus dilakukan agar kinerja guru meningkat. Supervisi diartikan sebagai aktivitas yang menentukan kondisi atau syarat-syarat yang esensial yang akan menjamin tercapainya tujuan-tujuan pendidikan. Supervisi yang dilakukan oleh kepala sekolah merupakan jembatan komunikasi antara guru dan kepala sekolah dalam memantau aktivitas mengajar guru dengan melihat bagaimana mereka menggali bahan pelajaran, menggunakan metode mengajar yang variatif, melaksanakan evaluasi serta membantu guru dalam menerjemahkan kurikulum sesuai dengan minat, kebutuhan dan potensi peserta didik. Supervisi akademik adalah bantuan profesional kepada guru melalui siklus perencanaan yang sistematis, pengamatan yang cermat, dan umpan balik yang objektif dan segera. Depdikbud (Fathurrohman dan Suryana, 2011 : 18) Tujuan utama supervisi akademik adalah untuk meningkatkan kemampuan profesional guru dan meningkatkan kualitas pembelajaran melalui pengajaran yang baik".

Supervisi ini diberikan oleh kepala sekolah kepada guru dalam rangka memperbaiki kinerja guru terutama pada perencanaan pembelajaran, pelaksanaan proses pembelajaran dan evaluasi proses serta hasil pembelajaran. Supervisi yang ada di sekolah dewasa ini lebih cenderung mengarah ke inspeksi, di mana supervisor dalam pelaksanaannya mencari-cari kesalahan dari pada guru tanpa ada sebuah pembinaan serta pembenaran atau perbaikan dari sesuatu yang telah disalahkan. Supervisi yang efekitf terwujud ketika supervisor memiliki kemampuan untuk menggabungkan keterampilan interpersonal dengan keterampilan teknis. Supervisor seperti itu dapat membangun penerimaan diri, moral, dan kepercayaan di antara dua belah pihak (supervisor dan guru).

Berdasarkan hasil wawancara yang dilakukan dengan kepala sekolah salah satu SMK di Bandar Lampung diperoleh informasi terkait permasalahan yang mendasari penelitian yaitu: Realita yang terjadi disekolah yaitu tidak tersusunnya program supervisi yang jelas oleh kepala sekolah dalam melakukan pengawasan. Penyebab kesemuanya itu diduga karena tidak terlaksananya supervisi akademik secara ideal, dan kalaupun ada kepala sekolah melakukan supervisi pelakasanaannya masih melalui pendekatan inspeksi yang terkesan supervisi itu hanya mencari-cari kesalahan dari guru tanpa bermaksud untuk memberi perbaikan atau bantuan terhadap kesalahan yang dilakukan oleh guru yang disupervisi. Masih terdapat guru yang belum mampu mengimplementasikan perangkat pembelajaran yang telah dibuatnya dalam proses pembelajaran, bahkan masih ada yang belum mampu membuatnya, sehingga kegiatan pembelajaran berjalan tanpa konsep yang jelas atau keluar dari konsep yang telah 
dibuatnya. Kenyataan yang terjadi, belum seluruhnya guru memiliki motivasi untuk mengembangan kemampuannya sehingga pembinaan dan program pengembangan profesional guru amat penting dilaksanakan.

Seorang guru harusnya mampu menjalan kan tugas dan tanggung jawabnya secara profesional apabila telah menguasai kompetensi guru yang telah ditetapkan pemerintah, dalam Undang-Undang tentang Guru dan Dosen, pasal 8 Undang-Undang Republik Indonesia nomor 14 tahun 2005, guru memiliki empat kompetensi yaitu: kompetensi pedagogis, kompetensi kepribadian, kompetensi sosial dan kompetensi professional. Upaya mengaplikasikan kompetensi tersebut diperlukan bantuan dan bimbingan dari supervisor untuk memberikan solusi. Hal ini sejalan dengan tujuan pelaksanaan supervisi akademik yaitu membantu guru mengembangkan kemampuanya mencapai tujuan pembelajaran yang dicanangkan bagi murid-muridnya. Berkaiatan dengan kompetensi supervisi, kepala sekolah berperan sebagai seorang supervisor yang bertugas membantu dan memfasilitasi guru dalam melakukan proses pembelajaran. Kepala sekolah sebagai supervisor mempunyai tanggung jawab untuk peningkatan kemampuan guru dalam mengelola kegiatan pembelajaran di sekolah serta mempunyai peranan yang sangat penting terhadap perkembangan dan kemajuan sekolah. Oleh karena pelaksanakan supervisi secara baik dan benar sesuai dengan prinsip-prinsip supervisi serta teknik dan pendekatan yang tepat akan meningkatkan kinerja guru. Pembinaan-pembinaan yang dilakukan kepala sekolah terhadap guru dapat meningkatkan kinerja dan dedikasi guru dalam dunia pendidikan.

Supervisi akademik (instruksional) dilakukan pengawas atau kepala sekolah, tujuannya diarahkan pada peningkatan kualitas pembelajaran oleh sebab itu penilaiannya lebih bersifat kualitatif yang diarahkan pada peningkatan kualitas pembelajaran. manajerial sekolah serta unsur sumber daya sekolah. Pelaksanaan supervisi akademik di setiap sekolah amat penting untuk dilakukan, yaitu suatu kegiatan yang direncanakan untuk memberikan bantuan kepada guru untuk meningkatkan kualitas pembelajaran. Pelaksanaannya dapat dilakukan pengawas atau kepala sekolah melalui dukungan dan penilaian proses pembelajaran di kelas. Supervisi akademik memberikan kontribusi pada kinerja mengajar guru sehingga mutu pembelajaran yang dihasilkan diharapkan akan semakin meningkat. Supervisi akademik dilakukan untuk melihat kualitas pembelajaran dari kinerja guru, setiap sekolah wajib melaksanakan upervisi akademik sesuai dengan pedoman, yang disusun secara terprogram (misalnya tiap semester dua kali) serta berkelanjutan.

Salah satu tugas kepala sekolah adalah melaksanakan supervisi akademik. Untuk melaksanakan supervisi akademik secara efektif diperlukan keterampilan konseptual, interpersonal dan teknikal. Oleh sebab itu, setiap kepala sekolah harus memiliki dan menguasai konsep supervisi akademik karena salah satu dimensi kompetensi yang harus dikuasai kepala sekolah adalah dimensi supervisi akademik. Supervisi akademik merupakan kegiatan pembinaan dengan memberi bantuan teknis kepada guru dalam melaksanakan proses pembelajaran yang bertujuan untuk meningkatkan kemampuan profesional guru dan meningkatkan kualitas pembelajaran. Kualitas belajar siswa sangat ditentukan oleh kualitas pembelajaran yang dihasilkan guru. Mengingat pentingnya pembelajaran yang berkualitas, diperlukan pembinaan dan pendampingan dari kepala dampingan sekolah dalam bentuk supervisi akademik secara berkelanjutan dengan tujuan agar proses pembelajaran guru di kelas menjadi semakin berkualitas dan memberikan kontribusi apda peningkatan hasil belajar siswa. Oleh karena itu dapat 
ditegaskan bahwa pelaksanaan supervisi akademik kepala sekolah sangat diperlukan untuk meningkatkan kinerja guru.

\section{METODE PENELITIAN}

Fokus penelitian ini adalah efektivitas pelaksanaan supervisi akademik kepala sekolah dalam meningkatkan kinerja guru di SMK Negeri 4 Bandar Lampung. Oleh karena itu, pendekatan yang dianggap cocok digunakan dalam penelitian metode deskriptif dalam pendekatan kualitatif. Penelitian yang menggunakan pendekatan kualitatif, bertujuan untuk mengkaji permasalahan dan memperoleh makna yang lebih mendalam sesuai dengan latar belakang penelitian. Metode penelitian yang digunakan dalam penelitian ini adalah deskriptif kualitatif. Menurut Bogdan dan Biklen (1998:96), penelitian kualitatif mempunyai lima ciri, yaitu: (1) dilakukan pada latar alami karena yang merupakan alat penting adalah adanya data yang langsung dari peneliti sendiri; (2) bersifat deskripsif, yaitu data yang dikumpulkan dalam bentuk katakata atau gambar; (3) lebih memperhatikan proses daripada hasil; (4) dalam menganalisa data cenderung induktif; (5) makna merupakan hal yang esensial. Metode penelitian kualitatif sering disebut metode penelitian naturalistic karena penelitiannya dilakukan pada kondisi alamiah atau natural setting

Jenis dan metode yang digunakan dalam penelitian ini adalah kualitatif maka instrument yang utama dalam pengumpulan data adalah peneliti sendiri. Peneliti merupakan instrumen penelitian utama yang wajib hadir sendiri secara langsung ke lokasi penelitian untuk memperoleh data. Kedudukan peneliti dalam penelitian ini berperan sangat komplek yaitu sebagai perencana, pelaksana pengumpulan data, analisis, penafsir data dan pada akhirnya peneliti menjadi pelapor hasil penelitian yang dilakukan penelitian di SMK Negeri 4 Kota Bandar Lampung Sebagai instrumen kunci.

Menurut Moleong (2001:168) menarik kesimpulan bahwa ciri-ciri umum manusia sebagai instrument mencakup segi responsive, dapat menyesuaikan diri, menekankan keutuhan, mendasarkan diri atas pengetahuan, memproses dan mengikhtiarkan dan memanfaatkan kesempatan mencari respon yang tidaklazim atau idiosinkratik.

Kehadiran dan keterlibatan peneliti di lapangan diketahui secara terbuka oleh subjek penelitian. Instrument pada peneltian terdiri dari instrument primer dan instrument sekunder. Instrument primer adalah peneliti sendiri yang melakukan wawancara di lapangan. Instrument sekunder berupa pertanyaan yang disiapkan dan dijawab oleh responden diantaranya kepala sekolah dan guru. Pengumpulan data dilakukan dengan pengamatan berperan dan wawancara yang mendalam, pengumpulan dokumen dan foto-foto kegiatan yang melibatkan tokoh-tokoh yang diteliti.

Data adalah keterangan atau bahan nyata yang dijadikan bahan kajian (analisis kesimpulan). Menurut Ahmadi (2005: 63) menyatakan bahwa : Data kualitatif adalah kalimat yang dikatakan oleh seseorang berkaitan dengan seperangkat pertanyaan yang diajukan peneliti. Sesuatu yang disampaikan oleh seseorang merupakan sumber utama data kualitatif, baik kalimat itu secara verbal melalui suatu wawancara atau dalam bentuk non verbal dengan kata lain bentuk tertulis melalui analisa dokumen atau respon survey.

Data primer adalah data yang diperoleh secara langsung dari sumbernya, seperti informan. Sumber data utama dalam penelitian ini adalah data yang langsung dikumpulkan oleh peneliti dari wawancara langsung kepada kepala sekolah. Sumber data sekunder adalah data yang telah tersusun dalam bentuk dokumen-dokumen, berupa 
data mengenai keadaan pendidik di SMKN 4 Kota Bandar Lampung, data prestasi serta dokumen yang diperlukan untuk menjawab fokus penelitian.

\section{A. Prosedur Pengumpulan Data Peneliti}

Sesuai dengan data yang diperlukan dalam penelitian ini, maka dalam pengumpulan data peneliti menggunakan beberapa prosedur, yaitu :

\section{Observasi Penelitian di Lapangan}

Observasi diartikan sebagai pengamatan dan pencatatan secara sistematis terhadap gejala ataupun fenomena yang diselidiki. (Marzuki,2000: 55-58). Dengan kata lain metode ini dilakukan dengan melihat langsung dan melakukan pengamatanpengamatan langsung disertai dengan pencatatan dan juga diperkuat dengan melakukan pendokumentasian di lapangan. Observasi Penelitian di Lapangan digunakan untuk melengkapi dan menguji hasil wawancara yang diberikan oleh informan yang kemungkinan belum holistik atau belum mampu menggambarkan segala macam situasi.

\section{Wawancara}

Wawancara atau Interview adalah sebuah dialog percakapan dengan maksud tertentu. Percakapan itu dilakukan oleh dua pihak, yaitu pewawancara (interviewer) yang mengajukan pertanyaan dan yang diwawancarai (intervewee) yang memberi jawaban atas pertanyaan itu. Wawancara adalah proses tanya jawab dalam penelitian yang berlangsung secara lisan dimana dua orang atau lebih bertatap muka mendengarkan secara langsung informasi-informasi atau keterangan-keterangan. (Cholid, $2005: 83$ ). Untuk mendapatkan informasi yang lebih detail peneliti melakukan wawancara dengan sejumlah orang yang berkompeten baik terhadap subjek penelitian maupun informan penelitian. Penelitian ini menggunakan teknik wawancara tak terstruktur. Alasannya adalah peneliti lebih luwes dan leluasa dalam memperoleh data melalui wawancara, maupun pertanyaan tentang efektifitas pelaksanaan supervisi akademik kepala sekolah dalam meningkatkan kinerja guru di SMK Negeri 4 Bandar Lampung tahun pelajaran 2020/2021.

Metode dokumentasi merupakan suatu teknik pengumpulan data dengan menghimpun dan menganalisis dokumen-dokumen, baik dokumen tertulis, gambar, maupun elektronik. (Nana Saudih, 2007: 221). Dalam penelitian ini selain menggunakan metode observasi dan wawancara, data penelitian dalam penelitian ini juga dapat dikumpulkan dengan cara dokumentasi, yaitu mempelajari dokumendokumen yang relevan dengan tujuan penelitian. Data dalam bentuk dokumentasi tersebut utamanya berkenaan dengan efektivitas pelaksanaan supervisi akademik oleh kepala sekolah dalam meningkatkan kinerja guru seperti program supervisi kepala sekolah, instrument penilaian supervisi, RPP dan SKP yang selanjutnya dianalisis.

Analisis data dalam penelitian kualitatif yang digunakan adalah dari berbagai sumber dengan menggunakan teknik pengumpulan data dilakukan secara terus menerus sampai datanya jenuh. Tujuan utama dari analisis data adalah meringkaskan data dalam bentuk yang mudah dipahami dan ditafsirkan. Menganalisis data dalam penelitian kualitatif adalah proses mensistematiskan data temuan penelitian dan menyimpulkan hasil wawancara, kemudian mengorganisasikan data dan disesuaikan dengan fokus penelitian. Data yang dianalisis adalah data hasil observasi dan hasil wawancara yang telah dilakukan. Interpretasi data dilakukan dengan mengacu kepada rujukan teoritis yang berhubungan dan berkaitan dengan permasalahan penelitian. Analisis data meliputi: reduksi data, display/penyajian data dan mengambil kesimpulan lalu diverifikasi. 
Pengecekan keabsahan data perlu dilakukan agar data yang dihasilkan dapat dipercaya dan dipertanggungjawabkan secara ilmiah. Pengecekan keabsahan data merupakan suatu langkah untuk mengurangi kesalahan dalam proses perolehan dan penelitian yang tentunya akan berdampak terhadap sebuah penelitian.

1. Kredibilitas (validitas internal).

Kredibilitas data adalah membuktikan kesesuaian antara hasil pengamatan dengan kenyataan yang ada di lapangan. Dalam pencapaian kredibilitas, peneliti menggunakan langkah-langkah, sebagai berikut:

a. Ketekunan pengamatan, peneliti mengadakan observasi terus menerus, sehingga memahami temuan data dengan lebih mendalam, sehingga mengetahui aspek yang penting, terfokus dan relevan dengan topik penelitian.

b. Mengecek kembali hasil laporan, yang berupa uraian data dan hasil interpretasi peneliti.

c. Triangulasi adalah teknik pemeriksaan keabsahan data dengan memanfaatkan berbagai sumber diluar data sebagai bahan perbandingan, kemudian dilakukan crosscheck, agar hasil penelitian dapat dipertanggungjawabkan. Trianggulasi yang dipergunakan dalam penelitian ini adalah trianggulasi sumber, trianggulasi metode. Penjelasan tentang tiga macam trianggulasi diatas, sebagai berikut:

1) Triangulasi dengan sumber, dilakukan dengan cara membandingkan data hasil pengamatan, wawancara dan dokumentasi, yakni membandingkan apa yang dikatakan orang didepan umum, dengan apa yang dikatakan orang secara pribadi, dan membandingkan prespektif seseorang, dengan berbagai pendapat dan pandangan orang lain.

2) Triangulasi dengan metode, dilakukan dengan cara membandingakan data yang diperoleh melalui teknik pengumpulan data yang berbeda dengan pengecekan derajat kepercayaan beberapa sumber data, dengan metode yang sama. Trianggulasi metode tertuju pada kesesuaian antara data yang diperoleh dengan data teknik yang digunakan.

\section{HASIL DAN PEMBAHASAN}

Dalam bagian ini akan dibahas serta didiskusikan beberapa hasil temuan penelitian yang sudah penulis paparkan sebelumnya. Berdasarkan pada fokus utama yaitu Efektifitas pelaksanaan Supervisi akademik kepala sekolah dalam meningkatkan kinerja guru di SMK Negeri 4 Bandar Lampung dan sub focus penelitian yaitu Pelaksanaan, peningkatan kinerja guru dan efektifitas supervisi yang dilakukan oleh kepala sekolah SMK Negeri 4 Bandar Lampung.

Untuk keefektifan pelaksanaan supervisi diperlukan suatu penyusunan program yang memuat berbagai aktifitas atau kegiatan yang akan dikerjakan oleh kepala sekolah dalam melaksanakan supervisi.

Sebelum dilakukannya pelaksanaan supervisi akademik, penyusunan program supervisi akademik kepala sekolah merupakan langkah awal dari rangkaian kegiatan supervisi karena program itulah yang akan menjadi panduan dalam pelaksanaan supervisi akademik. Untuk itu sebelum melaksanakan supervisi akademik haruslah menyusun program terlebih dahulu.

Berdasarkan temuan penelitian penyusunan program kerja supervisi akademik kepala sekolah di SMK Negeri 4 Bandar Lampung yang dilakukan oleh kepala sekolah bersama wakil kepala sekolah dan beberapa guru senior. Penyusunan Program kerja 
tersebut terdiri dari program tahunan dan program semester. Di dalam program tahunan kepala sekolah menyusun program supervisi di awal tahun pelajaran yang dijabarkan kedalam program semester terhadap guru-guru untuk meningkatkan kinerja guru.

Temuan penelitian di atas mengindikasikan bahwa penyusunan program supervisi yang dilakukan oleh kepala sekolah beserta timnya sebenarnya sudah mengakomodir temuan-temuan pada saat supervise dilakukan. Hal ini terlihat jelas dari konstruksi program supervisi akademik kepala sekolah yang sudah memaparkan materi yang berkaitan dengan kinerja guru yaitu perencanaan pembelajaran, pelaksanaan pembelajaran dan penilaian hasil belajar dalam bentuk kegiatan penilaian, pembinaan dan pemantauan.

Menurut Roger A. Kauffman, Nanang Fattah (2008: 49-50), menyatakan bahwa: Perencanaan adalah proses penentuan tujuan atau sasaran yang hendak dicapai dan menetapkan jalan dan sumber yang diperlukan untuk mencapai tujuan itu seefisien dan seefektif mungkin. Perencanaan merupakan Tindakan menetapkan terlebih dahulu apa yang akan dikerjakan, bagaimana mengerjakannya, apa harus dikerjakan dan siapa yang mengerjakannya. Untuk itu, perencanaan membutuhkan data dan informasi agar keputusan yang diambil tidak lepas kaitannya dengan masalah yang dihadapi pada masa yang akan datang.

Menunjuk pada konsep yang ditawarkan Roger A. Kauffman di atas, penyusunan program supervisi akademik kepala sekolah sebenarnya telah dilakukan sesuai dengan prosedur. Kegiatan tersebut sekurang kurangnya telah menggambarkan apa yang telah dilakukan, cara melakukan, waktu pelaksanaan, dan cara mengukur keberhasilan pelaksanaannya.

Dalam menyusun program supervisi akademik selanjutnya, kepala sekolah SMK Negeri 4 Bandar Lampung juga menyusun rencana tersebut secara sistimatis dan berdasarkan hasil analisis supervisi pembelajaran sebelumnya. Hal tersebut menandakan bahwa kepala sekolah sebagai supervisor telah memahami bahwa kegiatan apapun yang dilakukan adalah untuk memperbaiki proses dan hasil belajar dengan mengacu kepada terjadinya perubahan perilaku mengajar guru kearah yang lebih baik.

Kegiatan supervisi akademik merupakan kegiatan yang sangat penting dalam meningkatkan mutu pembelajaran. Kepala sekolah sebagai supervisor memiliki tanggung jawab untuk membantu guru dalam meningkatkan kinerjanya, agar guru dalam mengeloa proses pembelajaran dapat berjalan dengan baik sehingga mutu pembelajaran senantiasa dapat ditingkatkan.

Dalam proses penyusunan program supervise akademik kepala sekolah SMK Negeri 4 Bandar Lampung terlebih dahulu membuat keputusan dengan tetap memperhatikan aspek musyawarah. Hal ini dilakukan oleh kepala sekolah agar supervise bisa berjalan dengan lancar semua guru merasa terlibat dalam penyusunannya maka akan melaksanakannya dengan penuh tanggung jawab.

Maka berdasarkan paparan yang telah penulis dapat, bahwa dalam menyusun program supervisi kepala sekolah SMK Negeri 4 Bandar Lampung telah dibantu oleh beberapa guru senior yang dianggap berkompeten dalam hal supervisi. Program supervisi kepala sekolah SMK Negeri 4 Bandar Lampung adalah rencana kegiatan supervisi yang akan dilaksanakan oleh kepala sekolah dalam kurun waktu (satu periode) tertentu. Maka Pada temuan berikutnya dalam perencanaan supervisi akademik kepala sekolah SMK Negeri 4 Bandar Lampung adalah program supervisi akademik disusun 
pada awal tahun pelajaran yang terdiri dari dua termin, yaitu program semester ganjil dan program semester genap.

Berdasarkan temuan tersebut, dapat disimpulkan bahwa kepala sekolah SMK Negeri 4 Bandar Lampung benar-benar telah mempersiapkan program supervisi akademiknya dengan baik untuk meningkatkan mutu pembalajaran di sekolahnya. Hal tersebut dilakukan melalui berbagai pembinaan, bimbingan, dan membantu guru mengembangkan kemampuannya dalam mengelola proses belajar mengajar sehingga dapat meningkatkan kinerja guru itu sendiri. Kegiatan kepala sekolah dalam menyusun program supervisi tersebut di atas merupakan serangkaian kegiatan dalam pelaksanaan supervisi akademik.

Hal tersebut diperkuat dengan pendapat Menurut Muslim (2010: 41) "Supervisi akademik adalah serangkaian usaha pemberian bantuan kepada guru dalam bentuk layanan profesional yang diberikan oleh supervisor (kepala sekolah, pemilik sekolah dan pembina lainnya) guna meningkatkan mutu proses dan hasil belajar mengajar".

Temuan penelitian mengenai pelaksanaan supervisi akademik kepala sekolah SMK Negeri 4 Bandar Lampung yaitu:

1. Kepala sekolah menyusun program supervisi di awal tahun pelajaran yang dijabarkan kedalam program semester terhadap guru-guru untuk meningkatkan kinerja guru.

2. Kepala sekolah melakukan supervisi terhadap guru di mulai dari metode pengajaran sampai dengan aktifitas guru dalam pelaksanaan sistem yang telah di terapakan oleh sekolah tersebut.

Agar penyusunan supervisi akademik dapat berjalan dengan lancar, sebagai kepala sekolah perlu menetapkan aspek-aspek perencanaan yang meliputi 4 aspek yaitu:

1. Tujuan, Pertama yang harus direncakakan adalah, menetapkan tujuan supervisi akademik terlebih dahulu, di mana tujuan supervisi akademik di SMK Negeri 4 Bandar Lampung berorientasi pada peningkatan profesionalisme guru.

2. Sasaran, Berdasarkan tujuan tersebut, tahap selanjutnya menetapkan sasaran berdasarkan permasalahan yaitu upaya sekolah meningkatkan mutu kinerja guru dalam pembelajaran.

3. Langkah-langkah, Sebagai kelanjutannya kepala sekolah perlu menyusun Langkahlangkah yang meliputi: prosedur supervisi akademik, menetapakn guru yang akan disupervisi, sarana dan prasarana, serta mengkomunikasikan rancangan supervisi akademik tersebut kepada guru.

4. Waktu Pada tahap terakhir kepala sekolah harus menyusun jadwal supervisi akademik.

Kinerja guru pada dasarnya merupakan kegiatan guru dalam melaksanakan tugas dan kewajibannya sebagai seorang pengajar dan pendidik di sekolah yang dapat menggambarkan mengenai prestasi kerjanya dalam melaksanakan semua itu, dan hal ini jelas bahwa pekerjaan sebagai guru tidak bisa dilakukan oleh sembarang orang, tanpa memiliki keahlian dan kualifikasi tertentu sebagai guru.

Kinerja Guru dalam melaksanakan peran dan tugasnya di sekolah khususnya dalam proses pembelajaran dalam konteks sekarang ini memerlukan pengembangan dan 
perubahan kearah yang lebih inovatif, kinerja inovatif guru menjadi hal yang penting bagi berhasilnya implementasi inovasi pendidikan dalam rangka meningkatkan kualitas pendidikan/pembelajaran. Salah satu ciri tenaga kerja yang berkualitas adalah disiplin, yang berarti setiap tenaga pelaksana termasuk guru-guru harus mempunyai disiplin dalam melaksanakan tugasnya.

Berdasarkan temuan penelitian mengenai cara meningkatkan kinerja guru di SMK Negeri 4 Bandar Lampung. Program untuk meningkatkan kinerja tersebut terdiri dari: Pelatihan, Menurut Rivai (2005:225), "Pelatihan adalah proses secara sistematis mengubah tingkah laku untuk mencapai tujuan organisasi. Pelatihan berkatian dengan keahlian dan kemampuan untuk melaksanakan pekerjaan saat ini. Pelatihan memiliki orientasi membantu untuk mencapai kehalian dan kemampuan tertentu agar berhasil dalam melaksanakan pekerjaanya."

Dalam program pelatihan, sekolah melakukan pengiriman terhadap tenaga pendidik ketika mendapat undangan pelatihan. Tidak hanya pelatihan diluar sekolah, SMK Negeri 4 Bandar Lampung melaksanakan pelatihan didalam sekolah. Pelaksanaannya pun sesuai dengan langkah-langkah yang ada, mulai dari identifikasi masalah yang dihadapi guru sampai pada tindak lanjut dari kegiatan pelatihan.

Pelaksanaan pelatihan didalam sekolah yang biasanya dilaksanakan pada awal tahun pelajaran, seperti bedah kurikulum, penyusunan perangkat. Kegiatan pelatihan diluar sekolah seperti workshop peningkatan kompetensi penulisan karya ilmiah, peningkatan kompetensi guru mata pelajaran, kemudian pelatihan penyusunan naskah soal ujian sekolah berstandar nasional, sehingga dapat meningkatkan kemampuan serta keterampilan mengajarnya sehingga dapat mengambangkan proses belajar mengajar menjadi lebih baik.

Menurut Hasibuan (2014:69), "Pengembangan adalah suatu usaha untuk meningkatkan kemampuan teknis, teoritis, konseptual, dan moral karyawan, sesuai dengan kebutuhan pekerjaan atau jabatan melalui pendidikan dan latihan." Adanya program pengembangan kinerja guru yang mesti dilakukan selanjutnya adalah dengan cara supervisi Pendidikan yaitu supervisi yang sudah dilakukan adalah supervisi kunjungan kelas dengan melihat langsung bagaimana guru mengajar dikelas.

Kemudian dilanjutkan dengan supervisi individu yaitu mengajak guru untuk berbincang-bincang guna menindak lanjuti masalah yang terjadi, memberikan motivasi untuk memecahkan masalah yang ada. Agar pembinaan dan bimbingan terhadap guru yang dilakukan adalah dengan maksud mengoptimalkan kemampuan kinerja guru dalam meningkatkan pembelajaran.

Program yang selanjutnya adalah MGMP, program ini diikuti dengan baik oleh guru di SMK Negeri 4 Bandar Lampung bentuk dari kegiatan ini adalah musyawarah yang mana MGMP ini berada dalam suatu kepengurusan baik dalam provinsi, kabupaten, kecamatan, sanggar atau sekolah yang menjadi titik tolok dalam pengembangan kinerja guru. MGMP adalah suatu program pengembangan yang sangat baik bagi guru dalam meningkatkan pengetahuan. MGMP yang ada di SMK Negeri 4 Bandar Lampung. Pelaksanaan MGMP ini sudah diikuti lebih sering pada pengembangan dalam pembelajaran.

Program pengembangan guru yang terakhir adalah penelitian, dalam program penelitian ini dilaksanakan oleh kepala sekolah dalam bentuk penelitian tindakan kelas sehingga penelitiannya mengarah pada supervise. Penelitian tindakan kelas ini merupakan studi sistematik yang dilakukan guru melalui kerjasama dengan ahli 
pendidikan dalam rangka merefleksikan dan sekaligus meningkatkan praktik pembelajaran.

\section{Efektivitas Supervisi Akademik Kepala Sekolah Dalam Meningkatkan Kinerja Guru Di SMK Negeri 4 Bandar Lampung}

Evaluasi adalah pembuatan pertimbangan menurut suatu perangkat criteria yang disepakati dan dapat dipertanggungjawabkan. Menurut TR Morrison, Nanang Fattah (2008: 107-108), ada tiga faktor penting dalam konsep evaluasi, yaitu: pertimbangan (judgement), deskripsi objek penilaian, dan kriteria yang tertanggung jawab (defensible criteria). Tujuan evaluasi antara lain:

1. Untuk memperoleh dasar bagi pertimbangan akhir suatu periode kerja, apa yang telah dicapai, apa yang belum dicapai, dan apa yang perlu mendapat perhatian khusus.

2. Untuk menjamin cara kerja yang efektif dan efisien yang membawaorganisasi kepada penggunaan sumberdaya pendidikan (manusia/tenaga, sarana/prasarana, biaya) secara efisiensi ekonomis.

3. Untuk memperoleh fakta tentang kesulitan, hambatan, penyimpangan dilihat dari aspek tertentu misalnya program tahunan, kemajuan belajar.

Dalam aktivitas mengevaluasi, ada tiga kegiatan besar yang biasanya dilakukan supervisor, yaitu: identifikasi tujuan evaluasi, penyusunan desain dan metodologi evaluasi, serta pengukuran. Suharsimi Arikunto dan Lia Yuliana (2008: 396-397) mengidentikkan kegiatan evaluasi program yang dilaksanakan supervisor ini dengan kajian penelitian. Proses evaluasi merupakan upaya mencari suatu fakta dan kebenaran, dalam pelaksanaannya harus objektif dan rasional, prinsip metode ilmiah harus diterapkan. Ada beberapa Teknik evaluasi program yang biasanya dipakai oleh supervisor dalam rangka mencari data untuk tindak lanjut, yaitu: a) Test, b) Observasi, c) Laporan diri, d) Evaluasi diri, dan e) Teman sejawat.

Menurut Suharsimi Arikunto dan Lia Yuliana (2008: 397-398) beberapa prinsip yang harus dipegang teguh oleh supervisor dalam melaksanakan proses evaluasi, yaitu: Komprehensif, evaluasi harus dilakukan secara menyeluruh. Semua variable kegiatan dan aspek yang terkait dengannya harus dijabarkan dengan jelas sampai detail indikatornya. Kooperatif, untuk mendapatkan informasi yang lengkap diperlukan kerja sama antara subjek evaluasi dan objek evaluasi. Kontinyu dan relevan dengan kurikulum, evaluasi hendaknya dilakukan secara terus menerus, membidik semua tahapan kegiatan, dan saling bersambungan. Objektif, yaitu tidak terpengaruh dengan hal-hal yang bisa mengaburkan pengukuran dan penilaian. Humanis, yaitu mengedepankan dimensi-dimensi kemanusiaan. Aman, yaitu hendaknya menjaga privasi individu, tidak menebar ketakutan-ketakutan diantara objek yang di supervisi.

Berdasarkan temuan penelitian kegiatan evaluasi supervisi akademik di SMK Negeri 4 Bandar Lampung dilakukan dalam suatu siklus secara periodik setelah kepala sekolah melakukan penilaian, pembinaan, pemantauan, dan analisis hasil pengawasan dalam satu semester, dengan demikian kegiatan evaluasi supervisi akademik di SMK Negeri 4 Bandar Lampung dilakukan dua kali dalam satu tahun yaitu diakhir semester ganjil dan semester genap dengan melalui tahapan pembahasan hasil supervisi administrasi pembelajaran, pelaksanaan pembelajaran dan penilaian hasil belajar, kemudian dilanjutkan dengan analisia hasil pelaksanaan supervisi kelas. 
Kegiatan evaluasi ini dilakukan oleh kepala sekolah di SMK Negeri 4 Bandar Lampung sebagi supervisor yang dibantu oleh wakil kepala sekolah dan guru senior yang terlibat dalam kegiatan supervisi. Sedangkan manfaat dari pelaksanaan evaluasi supervisi akademik di SMK Negeri 4 Bandar Lampung adalah dijadikan sebagai alat ukur keberhasilan sebuah pendekatan, metode atau strategi supervisi yang telah dilakukanoleh kepala sekolah, serta dijadikan pertimbangan penyusunan program supervisi pada tahun berikutnya.

Pelaksanaan program tindak lanjut diawali dengan melakukan analisis kebutuhan peserta berdasarkan analisis hasil supervise akademik. Analisis kebutuhan merupakan upaya menentukan perbedaan antara pengetahuan, keterampilan dan sikap yang dipersyaratkan dan secara nyata dimiliki. Analisis kebutuhan ini dapat dilakukan dalam tahapan sebagai berikut:

1) Mengidentifikasi kebutuhan-kebutuhan terkait masalah-masalah pembelajaran dan kesenjangan apa saja yang ada antara pengetahuan, keterampilan dan sikap yang dimiliki guru serta yang seharusnya dimiliki guru. Perbedaan tersebut kemudian dikelompokan dan diklasifikasikan untuk menentukan jenis kegiatan tindak lanjut.

2) Mencatat prosedur-prosedur untuk mengumpulkan informasi tambahan tentang pengetahuan, keterampilan dan sikap yang dimiliki guru.

3) Mengidentifikasi dan mencatat kebutuhan-kebutuhan khusus pembinaan keterampilan pembelanjaran guru.

4) Menetapkan jenis pembinaan ketempilan pembelajaran guru.

5) Menetapkan tujuan pemilihan jenis pembinaan.

6) Mengidentifikasi dukungan lingkungan dan hambatan-hambatannya.

7) Mengidentifikasi tugas-tugas manajemen yang dibutuhkan untuk pelaksanaan tindak lanjut sumber-sumber belajar, sarana prasarana.

Selanjutnya ada tindak lanjut hasil supervisi, bentuk tindak lanjut supervisi akademik dapat dilakukan melalui kegiata sebagai berikut: Kegiatan pembinaan dapat berupa pembinaan langsung dan tidak langsung.

Pembinaan langsung dilakukan terhadap hal-hal yang sifatnya khsus, yang perlu diperbaiki dengan segera dari hasil analisis supervisi. Kegiatan pembinaan langsung yang dilakukan setelah kepala sekolah selesai melakukan observasi pembelajaran adalah pertemuan pasca observasi. Pada pertemuan ini kepala sekolah memberi balikan untuk membantu mengembangkan perilaku guru dalam melaksanakan proses pembelajaran.

Dari umpan balik itu pula dpat tercipta suasana komunikasi yang tidak menimbulkan ketegangan, tidak menonjolkan otoritas, memberikan kesempatan untuk mendorong guru memperbaiki penampilan dan kinerjanya.

Pada kegiatan ini kepala sekolah dapat melakukan lima Langkah pembinaan kemampuan guru yaitu menciptakan hubungan-hubungan yang harmonis, analisis kebutuhan, mengembangkan strategi dan media, menilai dan revisi.

Sedangkan pembinaan tidak langsung dilakukan terhadap hal-hal yang sifatnya umum yang perlu diperbaiki dan diperhatikan setelah memperoleh hasil analisis supervisi. Peran kepala sekolah dalam pembinaan tidak langsung adalah mendengarkan, memberi penguat, menjelaskan, menyajikan dan memecahkan masalah.

Berdasarkan temuan penelitian beberapa jenis komponen yang dapat dipilih kepala sekolah dalam pembinaan guru untuk meningkatkan kinerja guru adalah sebagai berikut: menggunakan pedoman atau petunjuk bagi guru dan pembantu guru lainnya 
secara efektif, menggunakan buku teks secara efektif, menggunakan praktek pembelajaran efektif yang dapat mereka pelajari selama bimbingan teknis professional/inservicetraining, mengembangkan teknik pembelajaran yang telah mereka miliki, menggunakan metodologi yang fleksibel, merespon kebutuhan dan kemampuan individual peserta didik, menggunakan lingkungan sekitar sebagai alat bantu pembelajaran, mengelompokan peserta didik secara lebih efektif, mengevaliasi peserta didik dengan lebih akurat/teliti/seksama, bekerja sama/berkolaborasi dengan guru lain agar lebih berhasil, mengikutsertakan masyarakat dalam mengelola kelas, memperkenalkan Teknik pembelajaran modern untuk inovasi dan kreatifitas layanan pembelajaran, membantu peserta didik dalam meningkatkan keterampilan berpikir kritis, menyelesaikan masalah dan pengambilan keputusan dan menciptakan suasana pembelajaran yang kondusif. Keberhasilan pelaksanaan supervisi akademik harus memiliki pengetahuan, sikap dan keterampilan yang dapat digunakan untuk mengoptimalkan kolaborasi, motivasi dan mendorong pertumbuhan personal maupun profesional guru dengan membangun hubungan yang baik. Keberhasilan pelaksanaan supervisi akademik supervisor harus menguasai: keterampilan menganalisis dalam gaya belajar mengajar serta memiliki keahlian dalam bidang pembelajaran dan kurikulum; Mampu melakukan kolaborasi dengan berinteraksi bersama para guru dan bertukar pemikiran; Memiliki pengetahuan yang relevan dalam komunikasi, hubungan manusia, hubungan kelompok dan resolusi konflik.

Kepala sekolah dalam menjalankan salah satu tugas sebagai supervisor mempunyai peran yang sangat penting bila melaksanakan tugas secara profesional dalam membina guru-guru, karena sesuai dengan tujuan supervisi akademik kepala sekolah sebagai supervisor harus memberikan layanan dan membantu guru dalam rangka peningkatan kompetensi profesional. Dampak dari bimbingan dan layanan yang diberikan kepala sekolah kepada guru tersebut dapat meningkatkan kompetensi guru Artinya bahwa supervisi akademik yang dilakukan oleh kepala sekolah dapat berjalan efektif maka akan memberikan dampak atau pengaruh positif dalam meningkatkan kompetensi guru.

Pekerjaan pemimpin tidak semudah yang dibayangkan terlebih di dunia pendidikan atau sekolah, sebab di dalam sekolah terdiri dari berbagai komponen yang berbeda, baik dari segi latar belakang pendidikan dan lingkungan sosialnya yang keberadaannya berada dalam satu wadah yaitu sekolah, sehingga masing-masing membawa budaya dan keinginan masing-masing, baik tingkat tenaga Pendidikan maupun siswanya. Kepala sekolah yang berhasil apabila mereka memahami keberadaan sekolah sebagai organisasi yang kompleks dan unik, serta seseorang yang diberi tanggung jawab untuk memimpin sekolah, oleh karenanya keberhasilan kepala sekolah dalam meningkatkan kinerja guru adalah kepala sekolah yang mampu menentukan titik pusat dan irama sekolah khususnya pada guru.

\section{KESIMPULAN DAN SARAN}

Berdasarkan tujuan penelitian dapat disimpulkan bahwa pelaksanaan supervisi akademik kepala sekolah di SMK Negeri 4 Bandar Lampung meliputi penyusunan program kerja mulai dari metode pengajaran sampai dengan aktifitas guru dalam pelaksanaan sistem yang telah di terapakan oleh sekolah. konstruksi pelaksanaan supervisi akademik kepala sekolah memuat aspek tujuan, sasaran, langkah-langkah dan 
waktu dan sudah memaparkan materi yang berkaitan dengan kinerja guru yaitu perencanaan pembelajaran, pelaksanaan pembelajaran dan penilaian hasil belajar dalam bentuk kegiatan penilaian, pembinaan dan pemantauan. Meningkatkan kinerja guru pada program pelatihan, didalam program pelatihan sekolah melakukan pelatihan diluar sekolah seperti melakukan pengiriman terhadap tenaga pendidik ketika mendapat undangan pelatihan. Evektifitas supervisi akademik kepala sekolah dalam meningkatkan kinerja guru

Bagi peneliti selanjutnya, agar melakukan penelitian lebih spesifik lagi agar hasil penelitianya lebih mendalam berkaitan dengan supervisi akademik.

\section{DAFTAR PUSTAKA}

Abu, Ahmadi., (2005). Strategi Belajar Mengajar. Bandung: CV. Pustaka Setia.

Achmadi, Abu dan Cholid Narbuko. (2005)., Metode Penelitian. Jakarta: Bumi Aksara.

Ahmad, L.O.I., (2017). Konsep Penilaian Kinerja Guru dan Faktor yang Mempengaruhinya. Makasar: Jurnal IDAARAH Vol. 1, 1.

Ahmad, Susanto., (2016). Manajemen Peningkatan Kinerja Guru. Jakarta: Prenadamedia Group

Akhmad, Syarief. (2012). Etika Profesi Pendidikan. Yogyakarta: LaksBang Pressindo.

Arikunto, S.(2006). Dasar-Dasar Supervisi. Jakarta: Rineka Cipta

Asnawir dan Usman, M Basyirudin. (2007). Media Pembelajaran. Jakarta: Ciputat Pers

Daradjat, Zakiah. (2006). Problema Remaja di Indonesia, Jakarta: Bulan Bintang.

Darmadi, Hamid. (2010). Kemampuan Dasar Mengajar. Bandung: Alfabeta.

Donni Juni Priansa dan Rismi Somad. (2014). Manajemen Supervisi dan Kepemimpinan Kepala Sekolah. Bandung: Alfabeta.

E. Mulyasa. (2011). Manajemen dan Kepemimpinan Kepala Sekolah. Jakarta: Bumi Aksara

Faturrohman, P dan Suryana, A. (2011). Supervisi Pendidikan (Dalam Proses Pembelajaran). Bandung: Refika Aditama.

Glickman, Carl. D., (1981). Developmental Supervision: Alternative Practice for Helping Teacherss Improve Instruction. Alexandria: ASC

Hasibuan, Malayu S.P. (2007). Managemen Sumber Daya Manusia Perusahaan, Bandung: PT. Bumi Aksa.

Husaini Usman. (2010). Manajemen, teori, Praktek dan Riset Pendidikan. Jakarta: Bumi Aksara

Jamal Ma'mur, Asmani. (2012). Tips Efektif Supervisi Pendidikan Sekolah. Yogyakarta: DIVA Press 
Jasmani \& Mustofa, Syaiful. (2013). Supervisi Pendidikan: Trobosan Baru dalam Kinerja Peningkatan Kerja Pengawas Sekolah dan Guru. Yogyakarta: ArRuzz Media

Kompri,. (2015). Manajemen Pendidikan .Bandung: Alfabeta.

M. Manullang. (2017). Dasar-dasar Manajemen. Jakarta : Ghalia Indonesia.

M. Manullang. (2017). Dasar-dasar Manajemen. Jakarta : Ghalia Indonesia.

Mangkunegara, A. A Anwar P. (2006). Evaluasi Kerja Sumber Daya Manusia, Bandung: Refika Aditama

Martiyono. (2014). Mengelola dan Mendampingi Implementasi Kurikulum 2013. Yogyakarta, Aswaja

Marzuki. (2000). Metodologi Riset. Yogyakarta: PT. Prasetia Widia Pratama.

Mukhtar dan Iskandar. (2009). Orientasi Baru Supervisi Pendidikan. Jakarta: GP Press.

Mulyasa. (2002). MBS: Konsep, Strategi Dan Implementasi. Bandung: PT Remaja Rosda Karya. , (2007). Standar Kompetensi dan Sertifikasi Guru. Bandung:

Remaja Rosda Karya.

Muslim, Sri Banun. (2010). Supervisi Pendidikan Meningkatkan Kualitas Profesionalisme Guru. Bandung: Penerbit Alfabeta.

Ngalim, Purwanto. (2012). Administrasi dan Supervisi Pendidikan. Bandung: Remaja Rosdakarya.

Piet A, Sahertian. (2010). Konsep Dasar dan Teknik Supervisi Pendidikan Dalam Rangka Pengembangan Sumber Daya Manusia. Jakarta: Rineka Cipta.

Rivai, dan Basri., (2005). Performance Appraisal Sistem Yang Tepat Untuk Menilai Kinerja Karyawan dan Menigkatkan Daya Saing Perusahaan, Jakarta: PT. Raja Grafindo Persada.

Sagala, S., (2010). Supervisi Pembelajaran dalam Profesi Pendidikan. Bandung:Alfabeta

Sahertian, A.P., (2008). Konsep Dasar dan Teknik Supervisi Pendidikan dalam rangka Pengembangan Sumber Daya Manusia. Jakarta:Rineka Cipta

Sanjaya, Wina., (2008). Perencanaan dan Desain Sistem Pembelajaran, Jakarta: Kencana Prenada Media Group.. 